\title{
Las narrativas
}

audiovisuales, un

desafío renovado

\section{The audiovisual narratives, a renewed challenge}

\section{As narrativas audiovisuais, um desafio renovado}

\section{GERARDOCASTELLI}

castelli@ort.edu.uy - Coordinador Académico, Licenciatura en Comunicación orientación Audiovisual, Universidad ORT Uruguay, Uruguay.

Este volumen de InMediaciones de la Comunicación es una nueva apuesta para seguir pensando el campo audiovisual. La complejidad de las narrativas audiovisuales en la era digital nos obliga a reflexionar sobre los procesos de creación, producción, realización y distribución que atravesamos, en parte como un cisma que ha puesto en crisis la concepción tradicional de la maquinaria audiovisual, en parte como un reto que alienta la búsqueda de modelos y métodos de trabajo afines a un tiempo histórico marcado por la hegemonía de las plataformas digitales.

En este sentido, la Escuela de Comunicación de la Universidad ORT Uruguay, y específicamente elárea de formación audiovisual, ha diseñado propuestas que buscan atender los cambios actuales y desarrollar alternativas académicas y profesionales en un sector siempre dinámico y complejo. En medio de esa vorágine a la que ha sido arrastrado el campo audiovisual, esta nueva publicación de InMediaciones de la Comunicación se traduce como un esfuerzo que invita a seguir reflexionando sobre las transformaciones que han tenido lugar en las últimas décadas. 
Eldesafío es constante yla multiplicidad de discursos y teorizaciones acerca de las narrativas que conviven en el ecosistema audiovisual hace que una mirada unificadora sea imposible. Las preguntas cambian de manera constante, y encontrar posibles respuestas exigencia repensar la complejidad del momento actual e intentar diseñar propuestas pedagógicas que expresen un modelo reflexivo-educativo-productivo capaz de adecuarse a los cambios de paradigma y brinde herramientas innovadoras para la creación de nuevos contenidos.

Dedicado al tema "Comunicación audiovisual: tradiciones, transformaciones y proyecciones", y con el inestimable aporte del Dr. Eduardo Russo como editor invitado, este volumen es un reflejo dela diversidad de temasy problemas que atraviesan el campo audiovisual. Un momento en el que el cine, tal como lo hemos conocido, ha dejado de ser el centro de atención y el arte audiovisual parece perder terreno ante el uso del audiovisual como herramienta (de comunicación), en un mundo hiperconectado que usa y abusa de las imágenes y, de manera extendida, devalúa la imagen a un objeto de consumo y rápido descarte.

Los entredichos que promueve tal estado de situación requieren el auxilio de la reflexión teórica, como respuesta y reacción, y la problematización de nuestro lugar como investigadores o docentes, quienes estamos inmersos en esa suerte de paradoja que supone la "resistencia de la imagen" ante el "abuso de la imagen”. Ese lugar ocupaba Marisol Álvarez, docente con una capacidad reflexiva única y exquisita que (nos) ayudó a pensar de un modo críticola producción audiovisual contemporánea. Su fallecimiento, en febrero de 2021, nos deja sin su compañía y lucidez. La dedicatoria de este volumen de InMediaciones de la Comunicación, y el texto de Álvaro Buela que sigue a estas líneas editoriales, es un tributo a ese legado insistente que invita a continuar la conversación.

\section{(c) BY}

Artículo publicado en acceso abierto bajo la Licencia Creative Commons - Attribution 4.0 International (CC BY 4.0) 